\title{
A SUBSUNÇÃO DA CATEGORIA SUPORTE DE GÊNEROS PELA NOÇÃO DE INTERAÇÃO
}

\author{
Antônio Duarte Fernandes Távora ${ }^{1}$
}

Resumo: Como os elementos que constituem o suporte como categoria podem ser usados na análise de gêneros e como o conceito de interação subsume a noção de suporte? Essa inquietação direciona a construção da discussão do presente ensaio. A tentativa de resposta para o problema de como o suporte, como categoria, pode ser usado na análise de gêneros parte da constituição material e da configuração formal, elaboradas em Távora (2008). Nesse texto, o autor trata a constituição material e a configuração formal como subcategorias que constituem o suporte e permitem explicar a relação suporte/gênero em diferentes possibilidades de pesquisa. É a partir da orientação teórica e metodológica posta por Bakbtin/Volochinov (2006) que se discute a segunda parte da questão apresentada. Conclui-se com um balanço do alcance das proposições teóricas levantadas neste ensaio.

Palavras-chave: Interação. Análise de gêneros. Suporte de Gêneros.

\section{INTRODUÇÃO}

De uma maneira geral, pode-se dizer que os primeiros autores a tentarem operacionalizar a análise da relação do suporte com o gênero são Maingueneau (2001) e Marcuschi (2003). A herança das contribuições teóricas desses trabalhos, neste ensaio, poderá ser facilmente visualizada pela retomada da noção de materialidade de Maingueneau, ou de forma de Marcuschi. Em Maingueneau, por exemplo, vê-se a aproximação através da noção de "força material dos discursos", que o autor elaborou a partir de Debray (1993), noção que impulsionou a construção da categoria de matéria como basilar para a noção de suporte de gêneros aqui defendida.

Igualmente, pode-se dizer que a ideia de forma é um conceito para a noção de suporte que passamos a considerar a partir da leitura de Marcuschi (2003), embora não da mesma maneira como ele a concebe. Para o autor, o suporte encerraria três aspectos: a) o de um lugar físico ou virtual, b) o de algo que tem um formato específico e c) o de uma funcionalidade de fixar e mostrar o texto.

1 Professor Adjunto da Universidade Federal do Ceará. Doutor em Linguística. Email: adftavora@gmail.com. 
Depreende-se da leitura que a) caracteriza como imprescindível o caráter material dos suportes; b) é fruto da observação da realidade que permite ver os suportes realizados empiricamente em um formato específico, como revistas e livros, o que implica que foram comunicativamente construídos para portar textos; c) revela a funcionalidade do suporte como um objeto que tem por finalidade fixar ${ }^{2}$ o texto e torná-lo acessível para fins comunicativos.

Apesar de as noções de matéria e de forma advirem dos autores acima, assumimos inteiramente as críticas direcionadas ao modo como foram reaproveitadas, dadas as modificações por nós empreendidas. Embora possamos dizer que a construção teórica aqui realizada é tributária dos autores citados, a categoria de interação não está na base dos conceitos de suporte de Maingueneau (2001) e de Marcuschi (2003) de modo explícito. Também se pode dizer o mesmo em relação a Bonini (2003, 2004, 2005), que, apesar disso, forneceu boas pistas para o entendimento da categoria de "forma" nos suportes de modo similar a como faz com a constituição formal do jornal, suporte por ele estudado no Projor (projeto em que ele estudou o jornal e seus gêneros).

É importante frisar que em Bonini (2005), gênero e suporte não são categorias tão independentes quanto se pode observar em Marcuschi (2003), para quem o suporte interfere no gênero. Já para Maingueneau, a mudança das condições materiais do discurso alteraria radicalmente o gênero do discurso. Isso faz-nos ver que o suporte não é concebido em relação ao gênero de maneira indiferente nesses autores. Essa noção de interveniência, portanto, é ponto comum que nos aproxima.

Os autores que se ocuparam do suporte como categoria, e citados aqui, de algum modo contribuem para a sustentação das discussões travadas neste ensaio. Contudo, nem todos os aspectos referentes à noção de suporte, nesses autores, serão tratados, por razão de espaço. Para o fim da discussão teórica interposta como objetivo deste ensaio, parte-se das categorias de materialidade e de constituição formal presentes em Távora (2008) para que se possa tratar da noção de interação como construção que subsume a noção de suporte.

\footnotetext{
${ }^{2}$ É estranho o fato de que o conceito de suporte de Marcuschi exclua a noção de armazenamento e ao mesmo tempo use o termo 'fixar' em relação ao gênero: quando se fixa, não se armazena um gênero no papel, por exemplo?
} 
É em razão dessa sequência matéria/forma como noções categoriais que se realiza a tentativa de organização das informações presentes neste ensaio: no primeiro momento desenvolve-se a noção de suporte sustentada pelo ensaio. Após as considerações relativas à noção, ou categoria de suporte como construção integral, constrói-se o arcabouço que o sustenta em termos de sua constituição parte a parte: desenvolve-se a noção de materialidade dos suportes, depois a de configuração formal. Em seguida, chega-se à seção que discute teoricamente como a interação subsume a noção se suporte. A penúltima seção do artigo discute aspectos empíricos do processo de interação com suportes/gêneros. Ao final do ensaio faz-se um balanço dos ganhos da perspectiva teórica construída.

\section{DESENVOLVENDO A NOÇÃO DE SUPORTE: MATERIALIDADE, FORMA E INTERAÇÃO}

Neste ensaio, compreende-se o suporte de gêneros como uma entidade capaz de estabelecer interação; para tanto, ele pode se realizar materialmente, o que implica uma arquitetura formal (TÁVORA, 2008). Forma não necessariamente é o arranjo da matéria que constitui o suporte (fato verificável em MARCUSCHI, 2003), como no caso da celulose, que, prensada, cortada e encadernada, forma o livro; mas também se refere ao modo de existência que a linguagem assume devido ao material sociotécnico responsável por seu registro (inscrição) e, consequentemente, pelo acesso. O suporte, como entidade de interação, que se realiza graças a uma materialidade formalmente organizada, é o que permite que se avaliem os processos de difusão aos quais os gêneros estão submetidos, sejam eles + orais ou + escritos. Isso significa dizer que até mesmo o contínuo que vai da oralidade à escrita pode ser explicado enquanto marcas dos processos de difusão, como se pode ver a seguir.

Esses processos de difusão podem ser vistos como "constritores da realização genérica", pois através deles se pode flagrar a dinâmica de como a matéria e a forma dos suportes garantem processos interativos. 
A matéria e a forma instituem procedimentos interativos nos suportes e, a partir desses procedimentos, pode-se ver a situação imediata (aspecto micro da interação) e o contexto social mais amplo (aspecto macro da interação). É nesse jogo de figura e fundo que os gêneros, como artefatos socialmente situados, realizam-se, e é nesse sentido que se pode afirmar que o suporte pode trazer ingerências para a análise de gêneros.

Entende-se, para efeito deste ensaio, que a matéria, a forma e a interação, além de serem divisadas como categorias teóricas que constituem a noção de suporte, também sejam compreendidas como categorias de ordem metodológica que, ao se ramificarem em outras subcategorias, possam ser utilizadas como critérios de análise capazes de revelar a influência dos suportes na atualização de gêneros em jornal, televisão, rádio, livro, etc.

\subsection{DA MATERIALIDADE DOS SUPORTES DE GÊNERO}

A matéria, dependendo do suporte analisado, pode se constituir em entidade material de registro e de acesso. Registro e acesso podem estar separados ou presentes em um mesmo suporte empírico, para que se possa falar em atualização de linguagens, consequentemente de gêneros (veja o esquema representativo na Figura 1).

Por difusão compreende-se um procedimento pelo qual realiza-se a transmissão de um processo comunicativo que pode se efetivar graças às materialidades de registro (arquivamento) e de acesso em que se verifica a atualização de linguagem(ns).

Por materialidade de registro define-se a superfície que se presta ao arquivamento de linguagem oral e/ou escrita, consequentemente de gêneros. O papel, como materialidade de registro, permite em sua superfície um procedimento em que se arquiva na mesma materialidade em que se dará o acesso à tecnologia de enunciação escrita. Pode-se dizer que, no âmbito da escrita impressa, apesar dos diferentes instrumentos tecnológicos que permitem procedimentos de impressão, o acesso, o registro e a atualização de linguagens e de gêneros se dão numa "mesma" superfície material.

Por materialidade de acesso compreendemos o dispositivo que permite a atualização de linguagem oral, escrita ou visual etc., 
independente de estar conjugada ou não a uma entidade material de registro. Um $\mathrm{CD}$ é um exemplo de materialidade de arquivamento. Graças a uma materialidade de acesso, o CD player, a atualização de linguagem nele registrada se torna acessível.

\section{Figura 1 - Diagrama da materialidade dos suportes:}

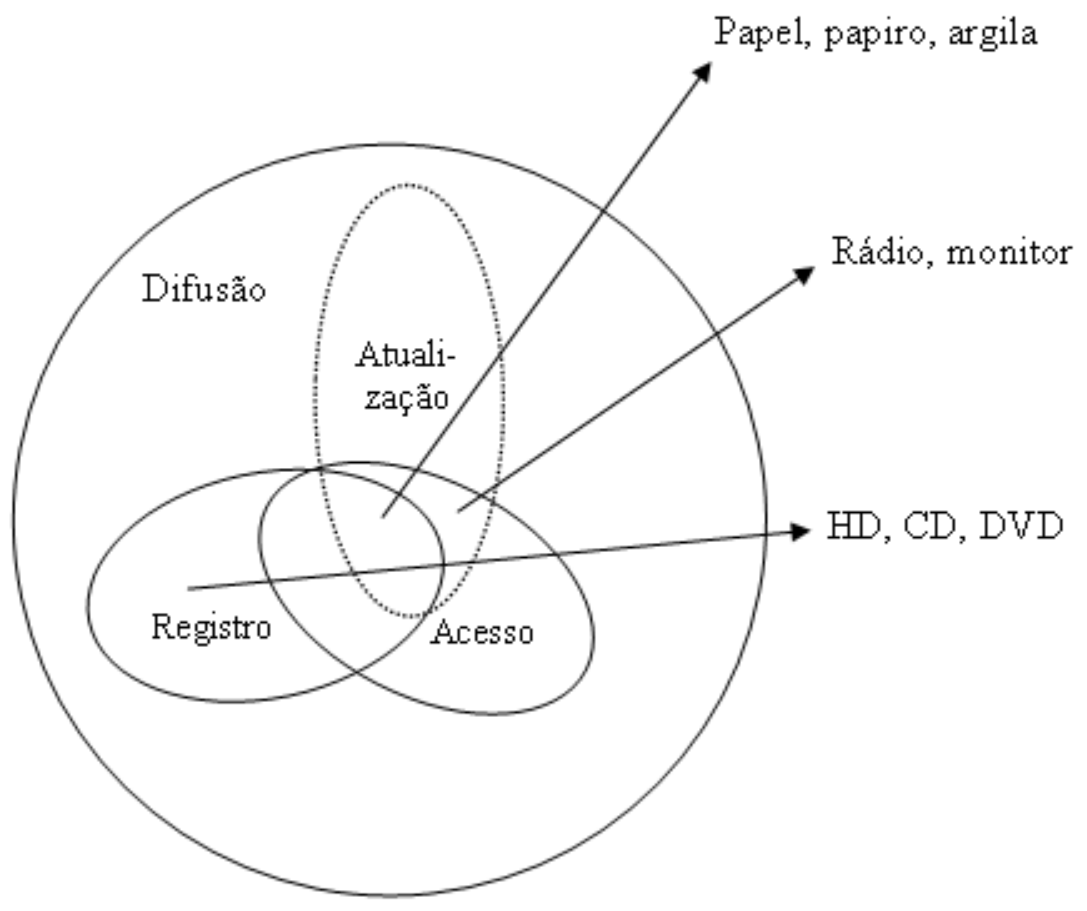

Fonte: Elaboração própria.

Os procedimentos de difusão são tão diversos quanto os suportes. Registro e acesso podem ocorrer ou não na mesma materialidade. No entanto, muitos suportes promovem um processo de difusão por permitirem que haja atualização, sem que haja registro. É o caso do rádio, que tanto pode estabelecer um processo de difusão através da 
reprodução de um registro em $\mathrm{CD}$, quanto permitir que a atualização de gêneros orais pelo locutor se torne acessível ao ouvinte sem que eles sejam objetos de registro.

Difusão compreende transmissão e, nesse sentido, acesso não deve ser compreendido em termos de emissor e receptor ${ }^{3}$ do quadro da Teoria Matemática da Informação, mas em termos de interatividade, dialogismo. Cremos que um processo de difusão se estabelece através das possibilidades materiais dos suportes: há aí um determinado tipo de acesso que constringe a atualização de linguagem; se oral, escrita, etc.

São os dispositivos de acesso que permitem uma interação de mão única ou dupla, que permitem a atualização de um contínuo de linguagem que pode ir do mais falado ao mais escrito. Bem entendido, os mecanismos de acesso podem permitir que exista um diálogo, como um modo de interação verbal; da mesma forma, também podem permitir que haja interação através dos "atos de fala impressos"”, virtuais ou radiofônicos.

Portanto, é em termos das possibilidades interativas, também estabelecidas pela materialidade dos suportes, que se tem acesso aos gêneros. Gêneros produzidos para um processo de difusão em que a materialidade do suporte, em razão de suas possibilidades de acesso, permite uma atualização oral/oralizada, escrita, imagética, uma combinação entre elas, ou todas reunidas. Gêneros produzidos para um tipo de interação possível do ponto de vista das condições materiais de acesso e para uma interação em que se veja "a situação imediata, mas também, através dela, o contexto social mais amplo" (BAKHTIN, 2006, p. 128).

\footnotetext{
3 Ainda que se possa aventar que sempre há emissor ou receptor localizáveis em um processo comunicativo, cremos que essa perspectiva evoca um conjunto de considerações que queremos evitar, como por exemplo, a noção de passividade na qual se veem imersos o emissor e o receptor. Responsividade e dialogismo não fazem parte desse circuito.

${ }^{4}$ Assim Bakhtin (2006, p. 127) se refere ao livro: como "ato de fala impresso". Aproveitamos a deixa para o paralelismo com ato de fala radiofônico e virtual.
} 


\subsection{DA NOÇÃO DE FORMA DE SUPORTES DE GÊNERO}

As materialidades de acesso, com suas configurações formais, são extremamente diversificadas, e qualquer processo que visasse descrevêlas teria que levar em conta as possibilidades de atualização de linguagens que elas permitem. Uma materialidade de acesso, como a tela de um computador, permite a atualização de linguagem não-verbal e verbal. $\mathrm{O}$ verbal, nesse suporte, poderia se atualizar através de uma tecnologia linguístico-enunciativa escrita ou da reprodução de um diálogo gravado em vídeo, que poderia ser visto e também ouvido graças à existência de um dispositivo multimídia no computador que permitisse sua reprodução sonora 5 .

Uma materialidade de acesso é índice das linguagens que podem ser atualizadas por ela: verbal ou não verbal. A linguagem verbal pode figurar em um contínuo que vai do + oral ao + escrito, respeitando-se as possibilidades de atualização da própria linguagem: se através de uma tecnologia linguístico-enunciativa que torna visual (ou mesmo tátil) o que era sonoro, ou se através da oralização daquilo que foi primordialmente concebido de forma escrita. Essas possibilidades de difusão da linguagem verbal podem oferecer o percurso das condições de atualização dos gêneros, o que, muitas vezes, justifica certas características neles identificadas como produto acabado.

Tais características são tão diversas quanto as materialidades de acesso. Elas dizem respeito aos procedimentos convencionados de como a linguagem e, por via de consequência, os gêneros se atualizam em dado suporte. O grau de convencionalidade dos processos de atualização de linguagens e de gêneros nos suportes é flagrável graças a um processo de formatação que se verifica na materialidade de acesso, que pode permitir a difusão de registros de linguagem e de gêneros ou apenas a atualização, a exemplo do que pode ocorrer no caso do rádio.

\footnotetext{
5 É importante registrar que o computador permite que sejam representados de maneira bidimensional vários suportes ou mesmo manter a arquitetura de origem desses suportes representados no universo virtual. O Jornal $O$ Povo, de Fortaleza, por exemplo, oferece uma versão virtual do jornal com diagramação exatamente igual àquela que sai impressa todos os dias. É possível, através da manipulação do mouse, folhear o jornal, virar páginas, dobrá-las na tela do computador do "mesmo modo" que se faz com o jornal em papel. O mecanismo de zoom facilita a visualização na tela do computador, dado que tal versão virtual realiza-se em tamanho menor que a original em papel (Cf. <www.jornalopovo.com.br>).
} 
Os procedimentos de formatação em uma entidade material de acesso não são unívocos para todos os suportes, pois os processos sociotécnicos envolvidos são diversificados e não tratam ou afetam a atualização de linguagens e de gêneros exatamente da mesma maneira. Em muitos casos, observa-se mesmo a não contribuição da formatação do suporte em relação à influência que poderia exercer em gêneros.

O contrário dessa perspectiva, no entanto, é uma inquietação de pesquisa relativa à inter-relação suporte/gênero que não grassa na academia em virtude da ausência de parâmetros que permitam discutir como se dariam tais contribuições. Os aspectos enfocados a seguir, pelas condições de difusão são, pretensamente, um caminho para se iniciar essas discussões.

A compreensão dos processos de formatação como configuração advém da observação de como se constituem as condições de difusão numa entidade material: se atualização de linguagem a partir de uma entidade de acesso separada da de registro; se atualização de linguagem a partir de uma entidade de acesso conjugada à de registro; se atualização de linguagem em uma entidade de acesso que prescinde de uma entidade de registro. Vejamos o quadro 1:

\section{Quadro 1 - Condições de difusão e a configuração formal do suporte:}

\begin{tabular}{|l|l|l|l|l|}
\hline $\begin{array}{l}\text { Situação material } \\
\text { de difusão }\end{array}$ & $\begin{array}{l}\text { Exemplos de } \\
\text { Suportes }\end{array}$ & $\begin{array}{l}\text { Possibilidades de } \\
\text { atualização (a) }\end{array}$ & $\begin{array}{l}\text { Fluxo } \\
\text { (b) }\end{array}$ & $\begin{array}{l}\text { Procedimentos de } \\
\text { formatação (c) }\end{array}$ \\
\hline $\begin{array}{l}\text { Entidade de } \\
\text { acesso separada } \\
\text { de uma entidade } \\
\text { de registro }\end{array}$ & $\begin{array}{l}\text { Tela do } \\
\text { computador }\end{array}$ & $\begin{array}{l}\text { Linguagens não- } \\
\text { verbal e verbal (oral, } \\
\text { oralizada e escrita, } \\
\text { imagens) }\end{array}$ & $\begin{array}{l}\rightarrow \\
\text { ou }\end{array}$ & $\begin{array}{l}\text { Diagramação na tela } \\
\text { realizada pela interface } \\
\text { dos softwares, } \\
\text { linkagem }\end{array}$ \\
\cline { 2 - 6 } & Televisão & $\begin{array}{l}\text { Linguagens não- } \\
\text { verbal e verbal (oral, } \\
\text { oralizada e escrita, } \\
\text { imagens) }\end{array}$ & $\rightarrow$ & $\begin{array}{l}\text { Edição, corte } \\
\text { diagramação, } \\
\text { sonoplastia, diç̧ão } \\
\text { estilística }\end{array}$ \\
\hline $\begin{array}{l}\text { Entidade de } \\
\text { acesso conjugada } \\
\text { a uma entidade } \\
\text { de registro }\end{array}$ & $\begin{array}{l}\text { Jornal, } \\
\text { revista, livro }\end{array}$ & $\begin{array}{l}\text { Linguagens não- } \\
\text { verbal e verbal } \\
\text { (escrita, imagens) }\end{array}$ & $\rightarrow$ & $\begin{array}{l}\text { Forma adquirida pelo } \\
\text { suporte, diagramação }\end{array}$ \\
\hline
\end{tabular}

Fonte: Elaboração própria. 
Os procedimentos de formatação observados em cada entidade de acesso serão diferenciados em razão de o suporte em que está inserida poder assumir: a) distintas possibilidades de atualização de linguagens verbal e não verbal; b) diferentes níveis de interatividade ditados pelo fluxo comunicativo e sua divisão, que interfere na recepção, no tempo e no modo de resposta, portanto na responsividade do co-enunciador ou coenunciador $^{6}$, o fluxo como subcritério também pode ser visto enquanto unidade, divisibilidade, sequencialidade ${ }^{7}$ espacial ou temporal flagradas nas entidades materiais de acesso; c) variadas funções e valores dos procedimentos de formatação: formas físicas, diagramação ${ }^{8}$, edição, corte, "linkagem", elocução estilística.

\subsection{DA INTERAÇÃO COMO CATEGORIA}

A interação é foco das preocupações do Círculo de Bakhtin. Em Marxismo e Filosofia da Linguagem (BAKHTIN/VOLOCHÍNOV, 2006) encontra-se uma discussão sobre a interação como realidade fundante para a linguagem, como se pode ver no artigo de Faraco (2005), que faz um balanço crítico do Congresso Internacional de Linguagem e Interação a convite da comissão organizadora. Na quarta seção do artigo ele afirma:

Dentre todos os filósofos que puseram o foco de suas reflexões na interação, foi Bakhtin o que mais avançou em termos de uma análise da linguagem. No chamado Círculo de Bakhtin, vai haver, aliás, um

\footnotetext{
${ }^{6}$ Mainguenau crê que o discurso é interativo e que em determinados momentos é difícil diferenciar quem é o destinatário, portanto adota o "co-enunciador" em lugar de destinatário, termo que exprime uma noção de passividade; já o termo "coenunciadores", sem hífen e no plural, designa os dois parceiros do discurso (MAINGUENAU, 2001, p. 54). Esta distinção será adotada por nós neste ensaio em razão de ela permitir um distanciamento das noções de destinatário ou receptor do quadro da Teoria Matemática da informação.

7 Os significados de sequencialidade a que nos referimos se aproximam dos encontrados no Dicionário Houaiss: " 3 - quantidade de coisas ou eventos consecutivos no espaço ou no tempo; série, sucessão; 5 - parte de uma obra escrita que guarda conexões com a(s) precedente(s); 9 Rubrica: cinema, televisão: conjunto de cenas ou planos desenrolados num só ambiente ou que tenham determinada unidade de ação" (HOUAISS, on-line).

${ }^{8}$ Vale salientar que os princípios de organização da textualidade não serão exatamente os mesmos nessas entidades em razão de as possibilidades interativas que eles instauram possuírem valores diferenciados e convencionados.
} 
frutífero encontro entre a reflexão filosófica e a científica, a primeira desenvolvida pelo próprio Bakhtin e a segunda, por Voloshinov (p. 217).

Abordaremos esse foco de reflexões sobre a interação a partir de Bakhtin/Volochínov (2006) em relação à linguagem, no qual se registra o "fenômeno social de interação verbal, realizada através da enunciação ou das enunciações" (p.127).

Para Bakhtin/Volochínov (2006, p.123) a verdadeira substância da língua não é constituída por um sistema abstrato de formas linguísticas, nem mesmo pela enunciação monológica isolada, ou pelo ato psicofisiológico de sua produção, mas fundamentalmente pelo fenômeno social da interação verbal que se realiza através da enunciação ou das enunciações.

É dentro desse quadro que se compreende o diálogo, como uma das formas de interação verbal, vista como uma das mais importantes. A compreensão de diálogo, nessa perspectiva, não se restringe à noção de comunicação em voz alta de pessoas colocadas face a face, é antes toda e qualquer possibilidade de comunicação verbal.

Para mostrar como essa generalização do conceito de diálogo pode ser transposta a outros processos igualmente ideológicos da comunicação verbal, Bakhtin/Volochínov (2006) evidenciam que o livro, ou seja, o ato de fala impresso, é também um elemento da comunicação verbal. A partir dele é possível uma série de discussões ativas, aspecto que evidencia que ele é feito para ser apreendido de modo ativo, ou para ser estudado a fundo, para ser comentado, criticado no quadro do discurso anterior, ou externado através de uma reação impressa, realizada em uma dada esfera de comunicação humana.

O dialogismo no qual o livro se insere como elo entre coenunciadores permite perceber que ele sempre é orientado em função de atos de fala anteriores. É por isso que o autor afirma que o discurso escrito é parte integrante de uma discussão e de um dialogismo em grande escala. Um livro responde algo, refuta algo, antecipa respostas, objeções potenciais ou procura apoio.

Em Bakhtin/Volochínov (2006), a noção de que os instrumentos de registro possibilitam acesso à enunciação, ou às enunciações pode ser 
nitidamente visualizada na diretiva que expõe a natureza do procedimento interativo do leitor com o ato de fala impresso. Nesse momento, ele explicita como o ato de fala impresso implica uma ação concreta de interação do leitor para com o livro quando o estuda a fundo, comenta-o, apreende-o de modo ativo.

Tanto o ato de fala impresso já é dialógico por estar inserido em discussão em larga escala, quanto a atitude do leitor, uma vez que ele responde a esse ato de fala em um discurso interior ou exterior, por exemplo, através de um diálogo com outros, ou de uma reação escrita numa resenha. Por esse aspecto se percebe que qualquer enunciação corresponde apenas a uma fração encadeada da comunicação verbal ininterrupta.

Essa última, por sua vez, representa um momento evolutivo de um grupo social determinado. É dessa relação que se estabelece entre a comunicação verbal ininterrupta e um grupo social determinado que se extrai a seguinte diretriz metodológica do Círculo: "o estudo das relações entre a interação concreta e a situação extralinguística - não só a situação imediata, mas também, através dela, o contexto social mais amplo" (BAKHTIN/VOLOCHÍNOV, 2006, p. 128).

Para o autor, não se pode compreender ou explicar a comunicação verbal fora do vínculo que ela estabelece com a situação concreta. Em decorrência disso, a comunicação verbal deve ser avaliada no emaranhado indestrinçável em que se vê envolvida com os outros tipos de comunicação, crescendo com eles sobre o terreno comum da situação de produção.

Essa inter-relação da comunicação verbal com outros tipos de comunicação é assim denominada pelo autor: comunicação global em contínua evolução. A percepção de que a comunicação verbal sempre está vinculada com a situação é o que permite avaliar gestos de trabalho ou atos simbólicos de um ritual como elementos de caráter não verbal. A comunicação verbal pode ser vista, nesses casos, como um mero complemento ou como elemento meramente auxiliar de tais gestos ou atos. 
É evidente que na perspectiva bakhtiniana, apontada no parágrafo acima, a noção de comunicação verbal focaliza processos de oralização em que o não verbal corresponde ao entorno situacional de uma circunstância de interação concreta. É óbvio, no entanto, que a comunicação verbal, como foi dito antes, não se realiza apenas em termos de oralidade, mas também como produção discursiva escrita. Retomemos agora a gradação dos processos interativos do curso exposto pelo autor e reproduzidos por nós até aqui.

Num primeiro momento, tem-se a noção de diálogo que é expandida como toda e qualquer comunicação verbal, consequentemente, dialógico é o modo constitutivo da linguagem verbal. É em razão disso que o autor exemplifica o ato de fala impresso, ou livro como um elemento da comunicação verbal com o qual mantemos um diálogo ativo, através de uma forma interativa específica. A atitude responsiva que se observa numa interação realizada através de um diálogo face a face, que é marcada pela mudança, ou tomada de turnos, tem outro modo de realização numa interação com um ato de fala impresso.

Isso não invalida a essência dialógica da comunicação verbal, ao contrário, ressalta-lhe os procedimentos diversos que se configuram como modo interativo: se através de uma apreensão no quadro do discurso interior em que criticamos, aceitamos ou refutamos; ou se através de uma exposição exterior que se realizaria, por exemplo, como uma resenha, elemento que daria, nesse caso, continuidade ao ciclo ininterrupto de comunicação verbal escrita através da atitude responsiva do resenhista.

O curso explicativo e de teorização de Bakhtin/Volochínov tem a continuidade marcada pela delimitação fracionária que qualquer enunciação representa, e que sempre retrata um momento da comunicação verbal ininterrupta, que por sua vez está associada a um grupo social determinado. Somente quando essa filiação discursiva é apontada é que se estabelece o que o autor denomina problema: "o estudo das relações entre a interação concreta e a situação 
extralinguística", compreendido aqui como marco teórico e como diretriz de análise.

Para o autor, essas relações assumem formas diferenciadas, que, associadas aos elementos de situação (comunicação artística ou científica), promovem significações diferenciadas. O pressuposto teórico resultante dessas relações é que a comunicação verbal jamais poderá ser explicada fora do vínculo que estabelece com a situação concreta. Logo após essa afirmação, Bakhtin adiciona a ideia de que a comunicação verbal está sempre associada a outras e com elas cresce sobre o terreno comum das condições de produção.

Como a perspectiva acima estabelece que não se pode isolar a comunicação verbal da comunicação global em perpétua evolução, conclui-se que a "língua vive e evolui historicamente na comunicação verbal concreta, não no sistema lingüístico abstrato das formas da língua, nem no psiquismo individual do falante".

A comunicação verbal concreta, com todas as diretrizes que a associam a um grupo e a uma comunicação global em perpétua evolução, é o ambiente ecológico em que a língua vive. Essa metáfora biológica em que a língua tem existência é determinada pelo espaço interativo humano e social. A língua como sistema abstrato de formas é consequência de uma ordem decrescente de encaixes: interação, formas das enunciações, formas abstratas da língua.

A configuração de existência social implica uma ordem metodológica para o estudo da linguagem, visualizada, na síntese abaixo:

1. As formas e os tipos de interação verbal em ligação com as condições concretas em que se realizam.

2. As formas das distintas enunciações, dos atos de fala isolados, em ligação estreita com a interação de que constituem os elementos, isto é, as categorias de atos de fala na vida e na criação ideológica que se prestam a uma determinação pela interação verbal.

3. A partir daí, o exame das formas da língua na sua interpretação lingüística habitual (BAKHTIN/VOLOCHÍNOV, 2006, p.129). 
Essa ordem é fundamental para se compreender a proposta metodológica para o estudo da linguagem (ou da língua) que, na perspectiva do Círculo de Bakhtin, é compreendida como interação e não como sistema (estrutura). Essa perspectiva, que aponta para a natureza da linguagem através de uma perspectiva interativamente social, é o que permite olhar para a natureza do suporte como entidade de interação. É o que será visto na próxima seção.

\subsection{COMO A INTERAÇÃO SUBSUME A NOÇÃO DE SUPORTE}

Os suportes se enquadram perfeitamente no primeiro elemento da ordem metodológica do Círculo ("As formas e os tipos de interação verbal em ligação com as condições concretas em que se realizam”), uma vez que as formas e os tipos de interação verbal tanto podem ocorrer através de um processo mediado quanto não. No caso de haver mediação por instrumentos tecnológicos, estes sempre poderão ser avaliados como geradores de processos interativos distinguíveis. Também se poderá avaliar o grau de filiação discursiva a que eles remetem, o que implica olhar para uma situação de comunicação (artística ou científica, por exemplo) como elemento que remete a uma condição concreta de realização.

Ainda se pode olhar para as condições concretas de um tipo de interação verbal em termos técnicos ou convencionados. Assim, um processo interativo de um leitor com uma materialidade responsável pela constituição de suporte em que se atualiza dado gênero poderá guiar certa constrição interpretativa da construção de sentido. É o que se pode evidenciar, por exemplo, na interação de um indivíduo com uma placa de bronze em que se atualiza uma lista de formandos com os seguintes dizeres: "Formandos 2010", tendo abaixo a lista dos nomes dos alunos. Exatamente a mesma textualidade impressa em papel e afixada em quadro de avisos mobilizaria os mesmos sentidos? 
Como compreender a relevância dos escritos ali atualizados senão pelo viés de uma compreensão social e convencionada dos valores que uma sociedade atribui a certa materialidade (bronze ou prata, por exemplo)? Ao mineral é atribuído um conjunto de valores que faz parte dos processos interativos em sociedade, e se tal mineral constitui uma entidade de interação, a atualização de linguagem deve ser vista em relação aos valores que essa associação reflete ou refrata.

Nesse sentido, a matéria de que se constitui a placa não impõe reverência; a reverência é parte integrante de um repertório de valoração que as situações sociais de interação fazem reverberar. É somente no ambiente social que o bronze ou a prata são vistos como elementos de fetiche. O escrito ali atualizado adquire certo valor interpretável em razão de a comunicação verbal estar associada a uma outra forma de comunicação, não verbal, mas ideológica: o fetiche atribuído à materialidade. Longe do circuito social de interação, o bronze ou a prata não representam valor algum.

Também em relação à materialidade, pode-se dizer que as possibilidades de registro, acesso e atualização de linguagens permitem determinados tipos ou formas de interação. As condições concretas em que se realizam essas formas ou tipos fazem com que a comunicação verbal, em sua relação inextricável com a comunicação global em perpétua evolução, admita tanto uma reação dialógica no quadro do discurso interior, quanto as mais variadas maneiras de se externar esse dialogismo constitutivo através de processos mediados ou não.

Se a comunicação verbal está inextricavelmente associada à comunicação global em perpétua evolução, como se pode observar na explicação do Círculo sobre o caráter auxiliar e figurativo da comunicação verbal oralizada em cerimônias, não se pode também negar que os suportes permitem um processo de inter-relação do verbal com o não verbal que deve ser visto em sua especificidade.

As distintas possibilidades de atualização de linguagens verificáveis nos suportes devem ser vistas como repertório convencionado de interrelação entre a comunicação verbal e a global, que não funcionam sob os mesmos parâmetros em suportes diferenciados. Há que se analisar como 
se dá a amálgama de ambas, como se inter-relacionam numa configuração formal, que deve ser flagrada em sua funcionalidade e como instanciadoras de processos interativos com o coenunciador ou co-enunciador. Veja-se, por exemplo, o caso da fotolegenda no jornal em relação à notícia; aquela pode ser vista como elemento independente ou indexado a esta (cf. BONINI, 2005, p. 70-72).

A comunicação global de que nos fala o Círculo pode ser especificada em termos de comunicação própria de um suporte. Assim, o global pode ser identificado como comunicação televisiva, radialística ou jornalística (impressa), como um conjunto flagrável de características capazes de identificar uma construção específica de processos comunicativos não verbais associados ao verbal nesses suportes.

Esse raciocínio é autorizado pelo fato de que, se a comunicação verbal é, muitas vezes, acessória num processo de construção simbólica em um ritual, teremos que ver uma comunicação verbal concreta, com todas as diretrizes que a associam a um grupo e a uma comunicação global em perpétua evolução, como ambiente ecológico em que a língua(gem) vive.

Essa metáfora biológica impõe olhar para as possibilidades de atualização de linguagens nos suportes como instanciadoras de modos interativos diferenciados: a) entre coenunciadores, b) entre um coenunciador e o verbal (escrito ou oralizado) que pode vir ou não associado ao não verbal. Acresce-se que essa associação do verbal e não verbal com o qual o co-enunciador interage deve ser analisada a partir do repertório convencionado de inter-relação entre a comunicação verbal e a não verbal do suporte em questão. Essa associação do verbal com o não verbal é parte constituinte do "ecossistema" em que a língua(gem) vive.

Apesar de essa metáfora biológica delimitar os elementos integrantes do "ecossistema da linguagem" - espaço interativo humano e social em que se realiza a comunicação verbal concreta, conjugada a uma comunicação global em perpétua evolução -, ainda não observamos, na análise de gêneros, as consequências de se avaliar as formas e os tipos de interação verbal ligadas às condições concretas em que ela se realiza. 
Isso significa dizer que não se tem observado os suportes como entidades de interação, eles não estão no primeiro plano de análise, mesmo para autores inscritos numa perspectiva interacionista. Aos suportes, aliás, é atribuída uma função redutora e objetal na literatura. Vejamos.

O suporte é visto como locus que se presta para fixar ou mostrar os gêneros (MARCURCHI, 2003), ou então como força material dos discursos (MAINGUENEAU, 2001), ou, numa perspectiva mais adequada que as anteriores, como objetos físicos ou convencionados (BONINI, 2005), mas não como entidade de interação.

Contrapostas às noções de suporte acima estão condições concretas em que se realiza a interação, primeiro elemento da ordem metodológica proposta pelo Círculo, seguida pela noção de gênero. Cremos que a retomada desse pressuposto interacionista subsume a noção de suporte, do mesmo modo que insere o gênero num processo reverso de autodeterminação, condicionado pelo paralelismo interação/gênero ou suporte/gênero constitutivo do processo.

\subsection{AFINAL, COMO INTERAGIMOS COM GÊNEROS E SUPORTES?}

Discutir o questionamento acima requer o auxílio do segundo passo do Círculo, visto aqui como orientação teórica e como condição de análise da relação suporte/gênero: "As formas das distintas enunciações, dos atos de fala isolados, em ligação estreita com a interação de que constituem os elementos" (BAKHTIN/VOLOCHÍNOV, 2006, p.129) preveem que os gêneros não podem ser avaliados distantes das formas e dos tipos de interação.

Não interagimos com os suportes e seus gêneros de modo igual, em razão de não serem exatamente as mesmas as possibilidades de atualização de linguagem. O modo ecológico de inter-relação do verbal e do não verbal é um exemplo de que os suportes devem ser vistos no campo comum das condições de produção. 
"As formas das distintas enunciações", ou as formas do gênero, devem ser vistas, nessa perspectiva, em associação estreita com a interação responsável pela constituição do próprio gênero. As formas e os tipos de interação, mediados ou não, são balizas do processo de constituição genérica. Há entre ambos, gêneros e tipos de interação, um processo reverso de autodeterminação. Esse processo pode ser avaliado em termos de interinfluência constitutiva se as condições de atualização de linguagens e seu modo ecológico de existência forem avaliados em termos de ingerência do suporte no tipo de interação e na inter-relação de linguagens que nele se realiza para a constituição de gêneros.

Nesse sentido, pode-se dizer que a configuração formal dos suportes é uma categoria que se mostra bastante produtiva, pois a partir dela se pode avaliar se estamos diante de processos de constrição genérica em razão de um tipo ou forma de interação que se estabelece em um suporte específico. Retomemos algumas observações lançadas antes sobre os elementos que constituem a configuração formal no sentido de se delimitar sua influência em processos interativos.

As distintas possibilidades de atualização de linguagens refletem os modos interativos e próprios permitidos por um suporte, no qual pode haver um repertório convencionado de inter-relação das linguagens verbal e não verbal; nesse sentido ambos os aspectos balizam a atualização de gêneros;

Os diferentes níveis de interatividade ditados pelo fluxo comunicativo se relacionam tanto às limitações interativas de ordem estritamente tecnológica do fluxo comunicativo, quanto à constituição convencionada da unidade, da divisibilidade, da sequencialidade em que esse fluxo se apresenta;

As variadas funções e valores dos procedimentos de formatação dizem respeito a ações convencionadas dos procedimentos de formatação aos quais o gênero está submetido.

Descrever as possibilidades de atualização de linguagens em um suporte compreende descrever como se realiza certo procedimento interativo, se entre coenunciadores ou entre co-enunciadores e se destes com um modo convencionado de inter-relação de linguagens. Nesse 
sentido, o item "a", acima, se apresenta como uma diretriz caracterizadora de certo procedimento interativo realizado sob certas circunstâncias, que permitem determinados modos de atualização genérica - escrita, oralizada - aos quais se somam possibilidades de interrelação entre linguagens.

Essas circunstâncias tanto podem ser vistas em termos de situação imediata quanto de contexto social mais amplo, enquanto fenômeno adstrito à interação como situação focal quanto ao enquadramento dessa interação no quadro social mais amplo em que se insere.

Nesse sentido e exemplificando o que foi dito acima, um suporte, como um jornal, permite uma análise do modo de interação focal quando se observa um procedimento interativo do leitor com um gênero cuja forma de composição é constituída para promover diferenciados processos de interação tanto com a materialidade linguística quanto com os elementos não verbais de comunicação que o constituem, por exemplo, as fotos.

A constituição de notícias por lide é um exemplo de como um gênero pode, em razão de sua constituição, e de dado suporte, promover níveis interativos diferenciados do leitor com a íntegra ou com parte do gênero, neste caso, com a notícia. O mesmo se pode dizer da fotolegenda, compreendida na análise de Bonini (2005) como elemento autônomo ou integrante da notícia. Esse aspecto diz muito do modo como interagimos com o jornal e com suas notícias, mas não só com elas, pois esse modo ecológico em que os gêneros vivem influencia o jornal como suporte.

Em termos de contexto social mais amplo, os suportes devem ser vistos como entidades de interação em que se identifica o dialogismo de uma comunidade discursiva (SWALES, 1990, 1992), de uma esfera de comunicação humana (BAKHTIN, 2000), de um domínio discursivo (MARCUSCHI, 2003); de uma protocomunidade discursiva, de comunidade discursiva simples ou comunidade discursiva complexa (BONINI, 2002). 
Nesse sentido, pode-se afirmar que as formas de interação em um jornal, balizadas por um dos conceitos acima, está na base da preocupação da academia como diretriz social delimitadora de um gênero. Essa diretriz, no entanto, não é a única.

Do ponto de vista histórico, os processos interativos do leitor com o jornal não foram baseados em uma situação concreta de atualização de gêneros realizada de modo imutável. O que se visualiza na materialidade textual de uma notícia nem sempre foi como se apresenta hoje. O modo de composição da notícia, como gênero, enfrentou transformações ao longo do século $\mathrm{XX}$ que dizem respeito tanto à materialidade genérica, através do aparecimento do lide nas notícias a partir dos anos cinquenta ${ }^{9}$, quanto aos processos de formatação do jornal como suporte (veja-se exemplo na Figura 2).

Essas duas capas têm ao lado uma representação gráfica e formulaica de sua composição. São nitidamente diferentes os processos de arranjo da materialidade textual com os elementos da visualidade aí presentes. Vejamos um comentário do autor sobre essa nova forma de arranjo no Jornal do Brasil:

Passa-se, portanto, de uma "ordem" gráfica acentuadamente simétrica, na qual se tinha uma anulação quase completa das possibilidades visuais do suporte de linguagem, para uma outra realidade em que a disposição da mancha gráfica contemplava um arranjo do qual faziam parte outros componentes visuais (valorização do espaço da página, utilização do recurso fotográfico, limpeza de adornos desnecessários, por exemplo), tornando mais "orgânicas" as relações entre os subsistemas que compunham a capa do JB (FERREIRA JÚNIOR, 2003, p. 84, aspas do autor).

\footnotetext{
${ }^{9}$ Vizeu e Mazzarolo (1999, p. 58) informam que "No Brasil, o lead foi introduzido por Pompeu de Souza, em 1950, no Diário Carioca”. Sodré (1983, p. 394) e Ferreira Junior (2003, p. 64) também fazem referência a essa introdução do lide no jornalismo do Brasil por Pompeu de Sousa, chefe de redação do Diário Carioca no início da segunda metade do século passado.
} 
Figura 2 - Capas do Jornal do Brasil em 1956 e 1959:
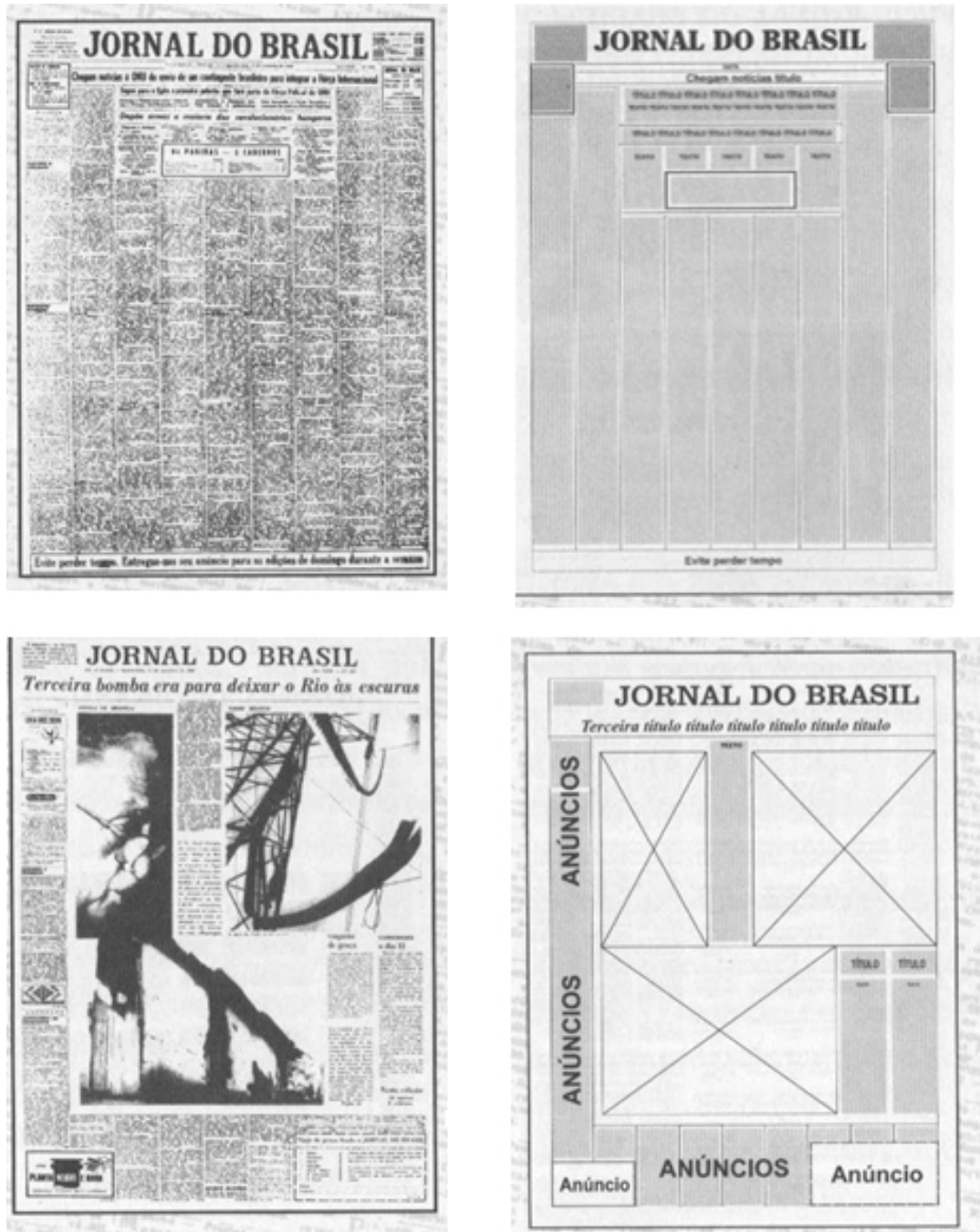

Fonte: Ferreira Júnior (2003, p. 85). 
Como se pode notar, a composição de linguagem verbal e não verbal no jornalismo brasileiro não parece algo tão definitivo como se poderia pensar. Os exemplos em tela têm cerca de cinquenta anos. $\mathrm{O}$ modo como interagimos com a resultante desse novo processo de integração de linguagens iniciado nos anos 50, no entanto, instituiu novas formas de nos relacionarmos com as linguagens no jornal e com o modo compósito que os gêneros passaram a apresentar no jornal.

Toda essa discussão sobre aspectos de composição nos suportes faz pensar: afinal, com o que interagimos quando nos deparamos com um suporte como o jornal? Com gêneros que podem ser identificados de modo bastante independente não parece ser a resposta (como se pode evidenciar em BONINI, 2005); mais parece que interagimos com gêneros que ocorrem ou funcionam associadamente em seções ou blocos.

$\mathrm{Na}$ realidade, interagimos com uma configuração formal em que os gêneros ocorrem atualizados sob diversos aspectos. Reconhecemos padrões de textualidade na mesma medida em que reconhecemos dado fluxo desse suporte, seja ele temático ou espacial.

Isso nos faz adentrar os diferentes níveis de interatividade ditados pelo fluxo comunicativo de um determinado suporte, item "b" da configuração formal dos suportes. Esse item se relaciona tanto às limitações interativas de ordem estritamente tecnológica do fluxo comunicativo, quanto à constituição convencionada de uma unidade ou divisibilidade de dado suporte.

As diretivas de letramento não podem passar distantes da organização da configuração formal em um suporte. $\mathrm{O}$ modo como interagimos com uma materialidade textual escrita associada a uma não verbal não é exatamente a mesma em suportes que permitem essa dupla possibilidade de atualização de linguagens. No jornal e na internet temos procedimentos interativos e modos de composição que não seguem a mesma "gramática". 
Assim, título e imagem podem formar um índice em uma página web, um elemento referenciador que remete ao lugar onde o gênero "charge animada10" pode ser acessado. O fluxo de um suporte é responsável pela sua divisão, unidade, partição, etc., que pode coincidir com o gênero ali atualizado ou não.

A noção de fluxo pode contribuir para as discussões da atualização dos gêneros nos suportes na medida em que, como subcategoria, permite diferenciar espaços físicos ou divisões temporais como unidades representacionais dos suportes, ou seja, as fronteiras dos suportes em que flagramos gêneros, um exemplar ou partes dele.

A ausência de um conceito similar tem feito especialistas denominarem gênero unidades de divisão de um fluxo, um segmento formal de um suporte, como o que se observa no caso do "gênero" quarta capa (CRISTOVÃO, 2005). Esse tipo de análise, em que o fluxo de um suporte é identificado como um gênero, é índice de quanto não se tem observado como se dá o processo de atualização; mais ainda, de como a atualização em um segmento de fluxo espacial de um suporte tem feito com que se conceba como gêneros as suas seções. Aliás, esse aspecto foi nitidamente exposto por Bonini (2005), que evidencia que os jornalistas, muitas vezes, entendem por gênero seções de um jornal que não se configuram assim.

Talvez seja esse encontro entre suporte, modo de organização da materialidade verbal e não verbal, coexistência de gêneros e constituição genérica aproximada que faça com que Bonini conceba o jornal como um hipergênero. A apropriação do conceito de gênero primordialmente baseada numa só diretriz de interação - a da comunidade discursiva, ou esfera de comunicação humana, que resulta numa configuração retórica de certo gênero - talvez seja a responsável pela ausência de estudos dos modos interativos que estabelecemos, como coenunciadores ou como co-enunciadores, ou seja, como leitores, telespectadores ou hiperleitores, com os diferentes suportes e seus gêneros.

${ }^{10}$ Ver o site <http://charges.com.br>, que pertence ao chargista e humorista Maurício Ricardo, criador das "charges animadas". 


\section{CONCLUSÕES}

Como as categorias de matéria e de forma podem ser usadas pela análise de gêneros e como o conceito de interação subsume a noção de suporte é o problema que orientou a construção do presente ensaio, em que se avaliou o alcance da proposição de como a interação pode ser considerada uma noção de ordem superior à qual o suporte está subordinado.

A noção do suporte como entidade de interação, vista através das proposições do Círculo de Bakhtin, permitiu evidenciar como a ordem metodológica para o estudo da língua(gem) propõe que as formas e os tipos de interação verbal ligados às condições concretas em que se realiza devem ser o primeiro aspecto a ser analisado quando se examina suportes e seu gêneros.

O conceito de suporte, enquadrado na noção de interação, e desmembrado em suas categorias, permite que se possa retomá-las para que se possa aferir como contribem para a análise de gêneros. Nesse sentido, pode-se dizer que as orientações dadas anteriormente em relação às categorias de matéria e de forma evidenciam novas possibilidades para o estudo da relação suporte/gênero, na medida em que oferecem critérios que se mostram promissores.

Pode-se afirmar, finalmente, que a (re)construção da categoria de suporte aqui empreendida, assim como as categorias propostas para a descrição do objeto, permitem a continuidade de pesquisas em análise de gêneros em um patamar mais adequado de análise.

\section{REFERÊNCIAS}

BAKHTIN, M. Estética da criação verbal. 2. ed. São Paulo: Martins Fontes. 2000.

2006.

Marxismo e filosofia da linguagem. 12. ed. São Paulo: Hucitec,

BONINI, A. Gêneros textuais e cognição. Florianópolis: Insular, 2002.

. Veículo de comunicação e gênero textual: noções conflitantes.

D.E.L.T.A., v. 19, n. 1, p. 65-89, 2003. 
. Em busca de um modelo integrado para os gêneros do jornal. In: CAVALCANTI, M. M.; BRITO, M. A. P. (Orgs.)

Gêneros textuais e referenciação. Fortaleza: Protexto - UFC, 2004.

Os gêneros do jornal: questões de pesquisa e ensino. In: KARWOSKI, A. M.; GAYDECZKA, B.; BRITO, K. S. (Orgs.) Gêneros textuais: reflexões e ensino. Palmas e União da Vitória, PR: Kaygangue, 2005. p. 61 - 78.

CRISTOVÃO, V. L. L. O gênero quarta capa no ensino de inglês. In: DIONÍSIO, A. P.; MACHADO, A.; BEZERRA, M. A. (Org.). Gêneros textuais \& ensino. 3. ed. Rio de Janeiro: Lucerna, 2005. p. 95-106.

DEBRAY, R. Curso de midiologia geral. Petrópolis, RJ: Vozes, 1993.

FARACO, C. A. Interação e linguagem: balanço e perspectiva. Calidoscópio, v.3, n.3, p. 214-221, set./dez. 2005.

FERREIRA JUNIOR, J. Capas de jornal: a primeira imagem e o espaço gráfico visual. São Paulo: Senac, 2003.

HOUAISS, Antonio. Dicionário Houaiss da língua portuguesa. Disponível em: < http://houaiss.uol.com.br/busca.jhtm>. Acesso em: maio 2010.

MAINGUENEAU, D. Análise de textos de comunicação. São Paulo: Cortez 2001.

MARCUSCHI, L. A. A questão do suporte dos gêneros textuais. DLVC. João Pessoa, v. 1, n. 1 p. 9-40, out. 2003.

SODRÉ, N. W. História da imprensa no brasil. 3. ed. São Paulo: Martins Fontes, 1983.

SWALES, J. M. Genre analysis - English in academic and research settings. New York: Cambridge University Press, 1990.

Re-thinking genre: another look at discourse community effects.

Comunicação apresentada em Re-thinking Genre Colloquium, Ottawa: Carleton University, 1992.

TÁVORA, A. D. F. Proposta de construção teórica para o conceito de suporte de gêneros. 2008. 178f. Tese (Doutorado em Linguística) - Programa de Pós-Graduação em Linguística, Universidade Federal do Ceará, Fortaleza, 2008.

VIZEU, A.; MAZZAROLO, J. Telejornalismo: onde está o lead? FAMECOS, Porto Alegre, n. 11, p. 57-63, dez. 1999. 
Recebido em: 08/08/2011. Aprovado em: 18/04/2012.

Title: The subsumption of the media as category in genre analysis by means of the notion of interaction

Author: Antônio Duarte Fernandes Távora

Abstract: How the elements that compose the media, as a category, can be used in the analysis of genres and how the concept of interaction subsumes the notion of media? Such unrest guides the discussion in this essay. The tentative answer to the problem of how the media, as a category, can be used in the analysis of genres is based on the material constitution and on the formal settings, as in Tavora (2008). There, the author treats the material constitution and formal constitution as subcategories, which compose the media and help to explain the relationship media/genre in several possibilities of research. The second part of the question is based on the theoretical and methodological orientation put by Bakhtin/Voloshinov (2006). The conclusion makes an assessment of the theoretical topics approached in this essay.

Keywords: Interaction. Genre analysis. Media.

Título: La subsunción de la categoría soporte de géneros por la noción de interacción Autor: Antônio Duarte Fernandes Távora

Resumen: Como los elementos que constituyen el soporte como categoría pueden ser usados en el análisis de géneros y como el concepto de interacción subsume la noción de soporte? Esa inquietud direcciona la construcción de la discusión del presente ensayo. El intento de respuesta para el problema de como el soporte, como categoría, puede ser usado en el análisis de géneros parte de la constitución material y de la configuración formal, elaboradas en Távora (2008). En ese texto, el autor trata la constitución material y la configuración formal como subcategorías que constituyen el soporte y permiten explicar la relación soporte/género en diferentes posibilidades de pesquisa. Es a partir de la orientación teórica e metodológica puesta por Bakhtin/Volochinov (2006) que se discute la segunda parte de la cuestión presentada. Se concluye con un balance del alcance de las proposiciones teóricas levantadas en este ensayo.

Palabras-clave: Interacción. Análisis de gêneros. Soporte de géneros.

Linguagem em (Dis)curso, Tubarão, SC, v. 12, n. 1, p. 299-324, jan./abr. 2012 